\title{
e-Dictionaries-based Semantic Gradient: Assisting Preschool Children Connect between Known and New Vocabulary
}

\author{
Yohannes Telaumbanua ${ }^{\circledR}$, Nurmalina ${ }^{2}$ \\ Bahasa Inggris, Politeknik Negeri Padang, Indonesia(1) \\ Pendidikan Guru Pendidikan Anak Usia Dini, Universitas Pahlawan Tuanku Tambusai, \\ Indonesia(2)
}

DOI: $\underline{10.31004 / \text { obsesi.v6i3.1680 }}$

\begin{abstract}
This study aimed at diagnosing the effects of e-dictionaries-based semantic gradients on preschool children's vocabulary improvement and digital technology's awareness. Observation and field-note were the techniques of collecting the data, the Bogdan \& Bilken's model was a technique of data analysis while triangulation was used to verify the data. The 25 preschool children were conveniently selected as research participants. They are aged between 4-6 years. The finding indicated that this study practically affects the children's ability to connect the known words and new vocabulary, understand the definition and shades of meaning of words, express ideas in simple and shorter sentences, and recognize the functions of digital technology's devices in the learning process. In conclusion, this strategy is incredibly useful for building children's English language intelligence and constructive awareness of the use of digital technology devices in the learning process.
\end{abstract}

Keywords: e-dictionaries; semantic gradient; known lexis; new vocabulary.

\begin{abstract}
Abstrak
Penelitian ini bertujuan untuk mendiagnosis efek gradien semantik berbasis e-kamus pada peningkatan kosakata anak-anak prasekolah dan kesadaran teknologi digital. Observasi dan catatan lapangan adalah teknik pengumpulan data, model Bogdan \& Bilken adalah teknik analisis data sedangkan triangulasi digunakan untuk memverifikasi data. 25 anak prasekolah dipilih dengan mudah sebagai peserta penelitian. Mereka berusia antara 4-6 tahun. Temuan menunjukkan bahwa penelitian ini secara praktis mempengaruhi kemampuan anak untuk menghubungkan kata-kata yang dikenal dan kosa kata baru, memahami definisi dan nuansa makna kata, mengekspresikan ide dalam kalimat sederhana dan lebih pendek, dan mengenali fungsi perangkat teknologi digital dalam bahasa. proses belajar. Kesimpulannya, strategi ini sangat bermanfaat untuk membangun kecerdasan bahasa Inggris anak dan kesadaran konstruktif penggunaan perangkat teknologi digital dalam proses pembelajaran.
\end{abstract}

Kata Kunci: kamus elektronik, gradien semantik, leksis yang dikenal, kosakata baru

Copyright (c) 2021 Yohannes Telaumbanua, Nurmalina.

$\square$ Corresponding author: Yohannes Telaumbanua

Email Address : yohannespnp@yahoo.com (Padang, Sumatera Barat, Indonesia)

Received 23 March 2021, Accepted 19 August 2021, Published 31 August 2021 


\section{PENDAHULUAN}

The basis from which the authors putting forward such an idea, "the e-dictionaries-based Semantic Gradient: Assisting the Preschool Children connect between Known Lexis and New Vocabulary," as the critical topic of discussion of this study strongly stands on the following rationales. Here the details are. Firstly, the preschool children studying English so far only recognize and understand that one lexis of English belongs to only one meaning, for example, "she eats her breakfast at 7.30 a.m. meaning "she puts it into her mouth, chews it, and swallows it." They do not recognize and understand that there are still other words or phrases that belong to the same lexis, namely, "has/have something" as in "she has her breakfast at 7.30 a.m." This signifies that the preschool children only distinguish and depend on one word and meaning in expressing something. Though this is not faulty, it is precisely monotonous in communicating their ideas. They do not know anything other than the word and its meaning. Secondly, different from their mother tongue which tends to have one meaning for one lexis, the words of English usually belong to multiple shades of meaning both synonymously and antonymously as in "driving." The word "driving" does not always mean "operating a vehicle" as known so far but it still has other key meanings anyway. Besides "operating a vehicle," synonymously it strongly links to the same interpretation and usage of "traveling somewhere, taking somebody somewhere, making somebody or something move, making somebody or something, do something or work, hitting something into something, motivating, pushing, forcing, etc or "cruel, ruthless, inhuman, etc" for examples, antonymously mean "kind-hearted, compassionated, merciful, etc (Ide \& Véronis, 1998)."

Subsequently, in terms of using digital technology, smartphones, tablets, and or personal computers where the e-dictionaries can be easily downloaded, installed, and operated (opened and used) have not yet been intensively and extensively exploited in developing preschool children's word knowledge and vocabulary skills of English. Illadvisedly, the selection and use of the appropriate strategies and e-dictionaries have not yet been excellently taken advantage of and capitalized to assist the preschool children to make connections between known lexis and new vocabulary. Digital technology devices are only used to play games, watch YouTube, and communicate with their parents. More importantly, the language learning strategies of teaching English for preschool children have not yet been able to improve the children linguistic intelligence, digital competence, Critical Thinking Skills (CTSs)/Higher-Order Thinking Skills (HOTS), and gradually considered promoting the $21^{\text {st }}$ century learning skills of Communication, Collaboration, Critical Thinking, and Creativity or widely recognised as "4Cs" (Trilling \& Fadel, 2009).

Theoretically, in the standpoints of the science of contemporary pedagogy, this study may possibly, firstly, refer to the humans' language development explicating that by nature those who study a new language whether it is a mother or foreign language begin without knowing and possessing words along with being unable to distinguish their meanings accompanying them. Gradually, s/he starts using his/her non-verbal communication such as babbling, crying, gestures, gaze, head orientation, body positioning, etc as signs of meanings of communicating or expressing his/her needs, yen, etc including his/her second basic sense of "hearing" the new and diverse sounds around (Fontenot, 2018). However, the children have been incapable of pronouncing any identifiable words, along with understanding and distinguishing the meaning of each word identified. Similarly, in today's digital world, children who are in the childhood phase without understanding the words and possessing the knowledge about them, start learning by fiddling with their parents, brothers, and sisters' smartphones.

Subsequently, the children then try to respond to their mother, father, or language teacher's voice. The response signifies that the children have recognized the words, understand and distinguishes their meanings progressively. Afterward, s/he attempts to enunciate two or more words like mama, yah yah (father), iyah iyah, etc which may be able to understand and distinguish the meaning of the word s/he is trying to say. The children can 
imitate and repeat sounds of the words s/he is hearing around (Ateah et al., 2008) and likely understand and distinguish the meanings of the sounds of the imitated words. Gestures, gaze, etc are substituted by possessing a number of words and are exploited when required (Crais et al., 2009). (Haslett \& Samter, 1997) explicate that the children speak one at a time in taking the turn (turn-taking). Here, they have been able to process the information, construct the ideas, contribute to the talks and react to the previous remarks, etc. Likewise, in their intensive interaction, the children are able to listen to, imitate, repeat, and understand a number of the words they directly hear from their parents and siblings and they encounter on mobile phones, applications, and YouTube for examples (some of the words), low bat, poor connection, signals, switch off, turn on, one week ago, subscribe, post, new, save, notifications, translate, chat, calls, new group, key pad, recent calls, contacts, etc.

These can all be gradually understood to distinguish the words' meaning and to connect one word to the other ones because they actively interact with the digital devices intensively. Theoretically, the processes of learning to connect sounds and syllables; link words to make sense altogether in one or more ideas; understand and distinguish words, interpret the meaning of words; and more importantly, form the abstract ideas because the children have been actively engaged in (Ateah et al., 2008; Conti-Ramsden \& Durkin, 2012). Further, the children's language development, understanding, and interpretation mostly take place and significantly develop in some social settings like schools, mosques, churches, markets, etc. Likewise, through real-life routine activities such as reading, writing, learning grammatical rules of pronouns, singular and plural, and communicating short ideas expand and extend children's first words acquisition. Such activities help them to develop their metalinguistic awareness and vernacular. The school-aged children facilitate them to continue to absorb the information to then be used for learning to communicate with others (Ateah et al., 2008; Haslett \& Samter, 1997; Strom et al., 1987).

Language researchers state that the children's cognitive dimension develops well in this stage as they are capable of remembering and understanding words, a little capable of distinguishing their meanings along with directly applying them in their daily life conversation and talks. These occur as they understand and appreciate the purposes of the talks. Understanding the rules of their L1 and using the words for the right purposes and context are the innate effects of participation and interactions in their family and social environments. Informal registers or widely known as "slang or colloquial speech" are due to the impact of having collective contacts and interface with a wide range of diverse channels of communication. There are the key factors of developing words' possession (mastery) and affecting their interpersonal communication. This occurs by the age of 10- (Ateah et al., 2008; Smith, 2005; Strom et al., 1987). Shortly, such the aforementioned processes assist children to acquire and develop L1 so that they communicate with one another; express thoughts and emotions; support thinking and problem-solving skills; and maintain social rapport.

The above scientific storylines of the first language acquisition (FLA) and its development can be used as the bedrocks of learning to enhance the preschool children's second language acquisition (SLA) or foreign language acquisition (FLA) as they have been able to capitalise on their cognitive domain processes of acquiring, developing, and understanding the words. In general, at the age of 5 years old, the children of Indonesian have started learning to acquire an SLA or FLA through the processes of learning English in the Early Childhood Education, English private tutoring, and digital interactions intensively using smartphones connected to the internet and the Web. There, the children learn English words, vocabulary, phrases, daily expressions, short/simples sentences, etc from their English teacher, pictorial English books and dictionary, interactive games, etc. Memorising, arranging jumbled words into correct sentences, arranging the words on the scale, matching words, labelling pictures, completing sentences; see, pronounce, spell in the correct order, and write down the words (SWG, 2020); crossing out the word that does not belong with the others in 
the group, etc (Pettigrew, 1995) are the techniques used by the children to learn spoken and written words of English.

These splendid techniques have, however, not yet strongly emphasized their single definition of the words, meaning relations, and shades of meanings as well. As a consequence, one word is exploited for multiple purposes and contexts. The choice and use of words with a specific context and purpose and the understanding of distinguishing the meaning of, "what makes the word, for example, leap different from bound and jump" are the preschool children's core problems of acquiring English words. In addition, the words and their meanings accompanying them are the most critical aspects of the SLA processes. This is precisely what makes it difficult for the children including the school-aged children to understand. The difficulty is because each English word contains multiple and different meanings, shades of meanings, and meaning relations with having diverse purposes and contexts of using it (Bolden, 2020).

Likewise, principally, the process of acquiring and understanding the L1 has a few index similarities with the process of acquiring an L2/FL. The index similarities are the children have the capacities to be aware of, to perceive, to understand and appreciate, and produce (manipulate and use) the words to communicate. Words that are packaged into a language are essentially used as a means of communicating ideas and expressing emotion (Katzner \& Miller, 2002; Kennison, 2014; Trask, 2007). The critical gaps between theories of the FLA and second language acquisition (SLA), however, lie in the different aspects of lexical (words) phonological (sound), semantic (meaning, shades of meaning, and meaning relations), syntactic (set of rules governing sentences), morphological (ways words are constructed with stems, prefixes, and suffixes) and grammatical (system/rules of ordering sentences) developments (Brandone et al., 2006; R. Brown, 1974; Luinge et al., 2006). In the FLA's theories, the children acquire words of their first, second, foreign, or signed language, along with their meanings through having collective contacts and interface with a wide range of diverse channels of communication around their social environment. The acquired words are then constructed into simple sentences to communicate (Friederici, 2011). However, as the major bedrock of SLA, the semantic theory plays critical roles in assisting the non-native learners of English to acquire, develop, understand words and distinguish their meanings which are then used to be in touch with one another. As the basic need of learning a new language, the theory, therefore, strongly urges the L2/FL children to first acquire words along with synchronously understanding their single definition and being capable of distinguishing their meaning relations and shades of meanings as well. The goal is to specify the use of the word based on its purpose and context. The signified meanings in the semantic theory are "lexical meaning, grammatical meaning, semantic meaning dealing with word meaning, and pragmatic meaning depending in context" (Löbner, 2002; Slabakova, 2010).

Thirdly, the semantic theories mainly focusing on placing emphasis on understanding and distinguishing the "meaning" (definition) of the lexemes (words), meaning relations, and their shades of meaning are the most critical and unavoidable chore in the SLA and the emphases are the most complex ones for the majority of Indonesian foreign language learner, especially for the L2/FL preschool-age children to deal with. This is in line with what (Löbner, 2002) puts forward that, "it is very difficult to describe the meaning of lexemes explicitly." The complexities of learning or acquiring the L2 are seen when the children use, explain, translate, and interpret these words, "large, huge, gigantic, giant, great, outsized, hefty, bulky, fat, etc," into or become one word, that is, "big." They extensively exploit the term "big" to explain "greater in size than usual or average; extremely large in size; extremely large in size, amount, or degree; much larger or more important than most others of its kind; very large/in amount or degree; much larger than usual or much larger than one would expect; large in size, weight, or amount; large and heavy; flesh on one's body and that s/he weighs too much, etc." Although the word, big, is acceptable to explain a wide range of the speaker or writer's intended meanings but still insufficient anyway for specifying the purpose of articulating or 
expressing it as English words are slightly different from each other. The sentences, "instead of using the capital letter $K$, they even said or wrote: she did not write big letter K or instead of using great cultural achievements of the past, they even wrote: Indonesia has big cultural achievements of the past. Such poor word choices are often found in their oral and written communication. The children assume that the word "big" strongly deals with describing something that is very large; explaining the meaning large in amount or degree; explicating something that is important, famous, or exciting; or elucidating someone who is successful and famous for their actions, knowledge, or skill. Likewise, what makes the word "frighten" different from "scare, terrify, horrify, haunt, obsess, spook, etc is the critical tenets the L2/FL preschool children need to acquire and master. Outlandishly, middle school and high school preschool children, and even college preschool children unconsciously experience such a practice as the pre-schoolers do.

Fourthly, linguistically, this research, "semantic gradients," deals with lexicology studying "words" including the forms, meaning, relationships of their meanings to the theory of knowledge (epistemology), specific, purposive and contextual usage; and morphological rules (Halliday \& Yallop, 2007; Kovalenko, 2011) which also directly links to the semantic studies investigating the "single definition of the words, meaning relations, and shades of meanings" such as 'love vs. affection', 'big vs. large' etc. These words, although they are synonym and related, have differences in usage and meaning whose function are more purposive and contextual (Löbner, 2002) and discourse analysis which is closely related to "lexical cohesion" of reiteration: repetition, synonymy, hyponymy, metonymy, antonymy; and collocations: grammatical collocations and lexical collocation. The lexical cohesion defined by Renkema, however, strongly deals with connection based on the words used and has no relationship at all between grammatical and semantic notions (Renkema, 1993). The studies put emphasis on words, definitions, meaning relations, and shades of meanings whose major functions are to understand human expressions through language. As explained, one of the general characteristics of a language is arbitrary. It is arbitrary as the relationships between "forms" (mostly V, N, Adjective) and their "meanings" cannot be sometimes proved logically. The meaning words (lexical terms) can only be well reflected and understood through its context or contextual relations because essentially "meanings" in a language is unclear or undecided (Andriyani, 2013; Cruse, 1986; Levin et al., 1991). Further, the indefinite or undetermined meaning of a word in a language occurs when the word deals with connotation or additional meaning, not denotation or original meaning (Andriyani, 2013), characteristics of a language such as arbitrary; social phenomenon; symbolic system; systematic; vocal, verbal and sound; non-instinctive, conventional; productive and creative; a system of communication; human and structurally complex and unique, complex and modifiable (Hakim, 2018), and relations of lexemes spotlighting or eliciting the meaning relations and shades of their meanings (Löbner, 2002).

Greenwood \& Flanigan (2007) explicate that "semantic gradient is basically a collection of interrelated words put along a scale (see figure 1) whose major goal is to aid the preschool children to recognise, understand, and distinguish the shades of meanings of English words, for examples, "hungry" and "starving" and the instances should not be first considered as synonym although the fact is that semantic gradient leads to signify the same as another word or expression which listed from the smallest part to the largest one, for instance, the continuum may be started from, "tiny, little, average, big, large, huge, etc (Steven A. Stahl, 2006). The children are expected to be able to create and add other words using the basic continuum. This study, however, focused on teaching the children to understand the shades of meanings of words and to be more specific and contextual to choose and use them in their receptive and productive skills of English listening, reading, speaking, and writing. The categories of word gradients are based on the topics such as movement words, green words, speaking word, bread, etc (Johansen, 2014) whereas the e-tools and other online resources are exploited to assist the children who do not have prior knowledge of the word meaning and have 
insufficient words to fill in the semantic gradients as illustrated below. After filling in the gap, each student, a peer or a group of preschool children provide their reasons for choosing the words. Finally, they write sentences using the words along the gradient based on the level, purpose, and or context of using it (the word) (Tyson, 2016).<smiles>[AlH2][IH][AlH2][IH][IH2][IH][IH2][IH][IH2]I</smiles>

Word Bank: crawl, prance, limp, meander, stroll, lope, dart, run, sprint, jog

softly

spoken | ------- |------ |------ |------ |------ |------ $\mid$ said

Word Bank: shouted, exclaimed, whispered, murmured, hissed, moaned, sighed, answered, muttered, whimpered

www.readwritethink.org

Figure 1: Semantic Gradient and its Word Bank/Word Box
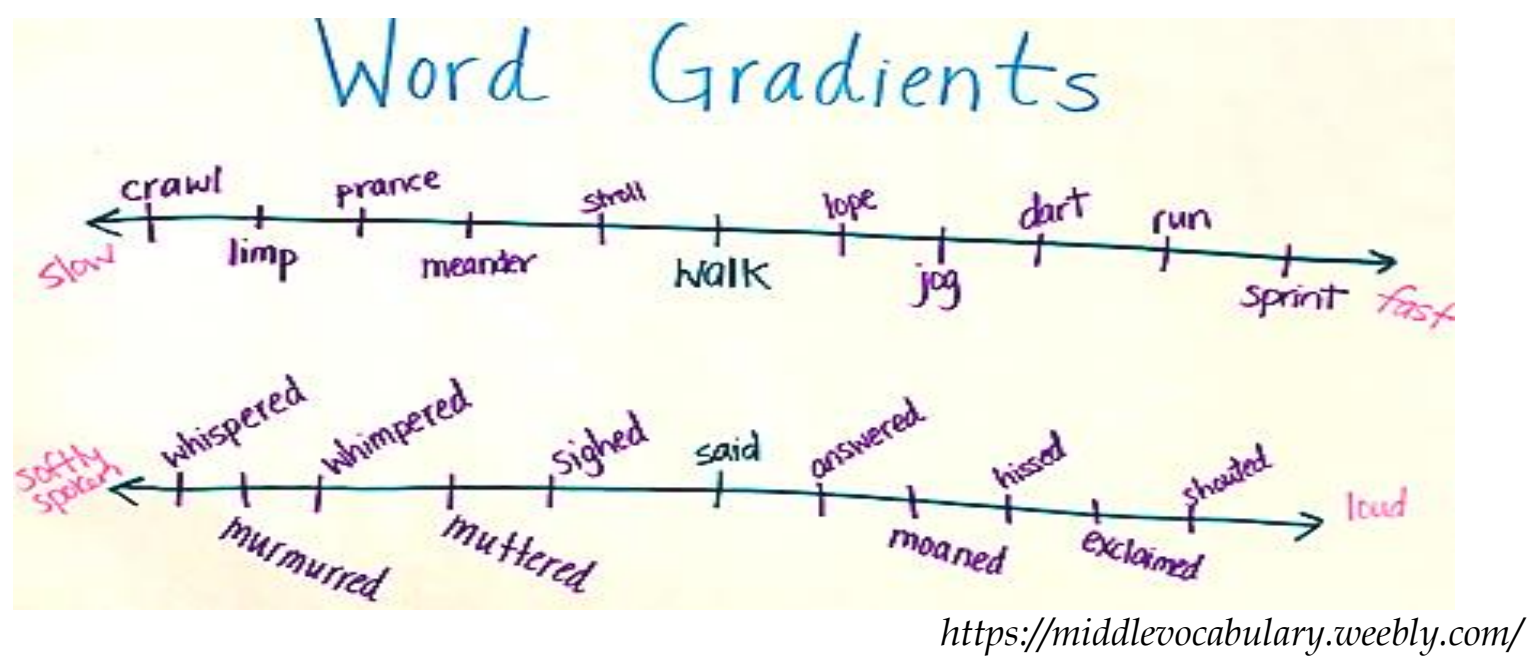

Figure 2: Semantic "Word" Gradients with Shades of Meanings of "Walk and Said"

From a series of explanations of the theories and concepts of FLA and SLA, the major purposes of conducting this research are to, firstly, to develop the preschool children's lexicology or words covering three aspects of "forms, meaning (definition or word meaning and shade of meaning) and use;" improve comprehension of spoken and written texts; and other areas of communication; assist them to learn the words in specific purposes and contexts; encourage them to develop other strategies to determine the word meaning $(\mathrm{H}$. D. Brown, 2007). Secondly, it is to improve the preschool children's words along with their shades of meanings and meaning relations; aid them to examine the differences between words; let them notice how many English words they can select and possess and understand the meanings; enhance their vocabulary knowledge, mastery, and possession so as to be capable of orally and in writing communicating their ideas; to be more sensitive to choose words (word choice); to deepen their understanding of word relations or connections lexically; broaden their understanding of a series of words based on the order of degrees; assist them to differentiate between shades of word meaning semantically; and help them express their ideas in written and spoken forms of simple basic sentences of statements, questions, requests, exclamations and compound sentences using coordinating conjunctions like for, and, nor, but, or, yet, so (Frank, 1972).

Thirdly, the authors attempt to gradually shift the children's English learning resources from conventional to digital ones as these tools (internet and the Web) offer unlimited 
resources for the children, rapid information, global awareness; connect the process of learning to acquire English words with semantic gradients using e-tools; help them recognise the functions and role of digital technology in the process of learning English words as FL, get closer and get them used to interact with the world of digital technology in developing English knowledge and skills of theirs, enhance their digital skills and digital literacy skills, authenticate and maximize vocabulary learning (H. D. Brown, 2007; Bull \& Ma, 2001; İlter, 2015; Tomlinson, 2012; Ningsih \& Mahyuddin, 2021)). To date, translating words from the source language (SL) into receptor language (RL) using a dictionary is a way of teaching English at the primary education level. This method is used when the number of words possessed by children who have insufficient word list or do not understand, for example, what "kuas" (paintbrush) means in English. The translation and understanding of English words' meaning are limited to relying on the primary meaning of that word while words affecting and determining the particular purpose and context of usage; encompassing other additional meaning components which occur in several surface structure lexical items or forms, for instance, "sheep" which also include other additional meanings such as "lamb, ram, ewe"; and the items or forms representing several alternative meanings, for example, as found in the Reader's Digest Great Encyclopaedic Dictionary that gives 54 meanings for one form/item have not yet become the priority scale of teaching and learning English words (Larson, 1984). The critical roles and uses of digital technology/e-tools (the Internet and the Web) in enhancing the children's understanding of words along with their shades of meanings are as flat as a pancake.

Fourthly, the significance of conducting this research is that every FL children first think of words when learning English because the words are the bedrock of easing them to speak the ideas of theirs (Barcroft et al., 2011). The words include vocabulary, lexical chunks, phrases, and expressions which empirically encourage FL learners to learn all these words to aid them to communicate even though having little grammar knowledge (Lewis. M., 1993). With having sufficient English words, there are some things which can be conveyed (Wilkins, 1972). The second importance, as (Lewis. M., 2002) puts across, is that the words are the heart of a language serving as developing the children's English fluency and expressions. The children should, therefore, acquire more to trigger them to productively communicate the ideas of theirs. The third implication is semantic gradients is one of the techniques/strategies that best assist the FL learners (children) to acquire and extend their English words. Basically, acquiring a lot of English words help the children to deeply appreciate and be in touch with one another. As Voltaire ever said that language is somewhat complicated to convey into words but Schmitt has a strong belief that all FL learners agree with what Voltaire ever pronounced. It cannot be, however, denied that having a large number of English words will bridge them easily achieve their learning achievement and attain certain purposes and goals (Schmitt, 2010). Furthermore, the fourth exigency is that the semantic gradients' practical effects can facilitate the FL preschool children master three aspects of the English word. Theoretically, each word has three key aspects, that is, forms including pronunciation, spelling, prefix, root, and suffix. The second aspect is the meaning of the word encompassing the reference or representation of what one says or of what first comes to one's mind when dealing with or thinking of those words. The last is the use of that word. This links to the grammatical and lexical collocations (Nation, 2001).

Fifthly, why e-tools? In contrast to 25 years ago, today, developing a "love" for learning and mastering English words is primarily due to the ease of the effects of the e-tools that are always changing, challenging, demanding and growing reality. Such e-tools ease both teacher and the children to instantly expand their English vocabulary in the blink of an eye and in many diverse ways. The existence of the internet and the web rapidly expose the online authentic texts with new words that are sometimes difficult to understand their meaning, meaning relations and even shades of meanings and by the e-tools close by automatically accelerate the steps of each language teacher and children check them in the online dictionaries 
or other tools. These kinds of words always fascinate the children and help them to specify the purposes and context of using them (Ur, 2012; Mardhotillah, Huda \& Rakimahwati, 2021).

Lastly, the e-tools-assisted semantic gradients offer a wide range of words and define word meanings, explain the meaning relations and shades of meaning; allow the teacher to easily adjust (customise) words so that the children can practice with the content or unitspecific words, review the language and play games with that language. The benefits of exploiting such e-tools (such as Reference Tools: Lingro, Lexipedia, Shahi, Snappy Words, visual dictionary online, Word Hippo, Wordnik.com, Your Dictionary, Math Words, A Maths Dictionary for Kids; Word Clouds: Wordle, WordSift, Tagxedo; Games and Review: Flashcard Stash, Vocabulary Games, Vocabulary Spelling City, VocabAhead, Free Rice; Word Walls $\mathcal{E}$ Virtual Field Trips: Padlet, ThingLink, TrackStar) which are believed can build the children's SLA. The e-tools-assisted semantic gradients are assumed to better enhance the school children's English learning. Even though this strategy, semantic gradients, has been widely employed at various levels of primary and secondary education, the study on the use of the etools-assisted semantic gradients to facilitate the children distinguish the shades of meaning of English words have not yet been intensively explored in the Indonesian EFL classroom (Johansen, 2014; Tyson, 2016).

Therefore, the purposes of this research were to introduce the uses of the e-dictionaries and the 21 digital tools in the English learning processes to the children; to aid them to build their foreign/second language acquisition of English words through e-dictionaries-based semantic gradients; to help them make the connections between known word and new words (vocabularies); to assist them to distinguish the shades of meaning of English words; to expose them models of how the topic/theme, for example, angry and its related words, for instances, annoyed, irritated, fuming, heated, cross, etc are purposively and contextually used within the sentences; diagnose the multiplicative effects of the e-tools-assisted semantic gradients on the preschool children's linguistic intelligence (competence) and digital skills. The research question was "did the e-dictionary-based semantic gradients have impacts on the preschool children's linguistic intelligence (competence) and digital skills."

\section{METHODOLOGY}

The scientific method of "observation" employed in this qualitative research aimed at focusing on making-meaning (Krauss, 2005; Yusuf, 2014) or finding meaning and understanding, verstehen, as regards the impacts of e-tools-assisted semantic gradients on the preschool children's linguistic intelligence (competence) and digital skills.

The preschool children numbering 25 participants were conveniently chosen for research purposes. The children were accidentally chosen from various schools. They were gathered to learn English. The use of this kind of sampling, which is mostly branded as convenience sampling, haphazard sampling, grab sampling, accidental sampling, incidental sampling, or opportunity sampling, was due to the relative ease of access to the research participants (subjects) because the subjects were readily available, expediting the data collection, saving times, and research expenses or cost-effectiveness (Christensen et al., 2012; Fernández-Martínez et al., 2012; Given, 2008; Henry, 1990; Teddlie \& Yu, 2007; Wright, Julius Sim, 2002). This research lasted for 6 months while the learning process took place three times a week where each meeting lasted for 120 minutes. Padang West Sumatra Province-Indonesia was the locus of the research. The followings are the teaching and learning procedures. Teaching and learning procedures can be seen in table 1 .

The researchers were the key instruments for gathering and assessing the information and expected data. The techniques, on the other hand, employed in collecting the data were, first, observation of "complete observation" where the researchers were naturally involved in the teaching and learning processes so as to ease them to collect the data. The second was fieldnote. This technique was made uses of recording descriptive or factual data of time, date, condition of the research setting, children's social environment, descriptions of research 
participants being studied and their roles in that situation, etc. Besides, it was to record the researchers' reflective information (questions, notions, concerns, etc) as regards the observation being carried out (Canfield, 2011; Labaree, 2020). The last was the unstructured interview. At the end of this study, preschool children were provided $10 \mathrm{w}$-h open-ended questions inquiring about the effects of the e-tools-assisted semantic gradients on their linguistic intelligence (competence) and digital skills (Chilisa, 2012).

Table 1. Teaching and Learning Procedures

\section{What does a teacher do?}

1. Introduce (review) the very basic forms and rules of English grammar focusing on using "be, adjectives, adverbs, nouns, verbs and pronouns. Here, the teacher gives a model of how to practically use these very basic forms and rules.

2. Introduce ways of exploiting technology and e-tools to enhance word knowledge of English. Here, the teacher gives a model of how to use the tools to enhance the word knowledge

3. Introduce the concepts of Semantic Gradients. Here, the teacher gives a model of how to make connections between known words and new vocabulary so that the children are able to distinguish the shades of meaning of English

4. Coach and train the children to accomplish the tasks.

5. Have the children discuss the reasons for putting the word on a continuum or certain spot/scale.

6. Listen to the children's English presentation.

7. Assess the children learning, group/pair discussion, performance. etc. "Excellent, Good, Fair, Poor" are technical terms used to measure the children's levels of performance. Nice work or a good job is another way of giving genuine praise.

8. Provide feedback and learning reflection

Subsequently, due to its own descriptive, inductive, narrative and continuous basic characters, the data have been begun to analyse when researchers collected data using (Bogdan \& Biklen, 2006) model. The steps were to narrow the study, determine the type of the research
- Listen to their teacher's explanation.

- Work in pairs and or in a group of 3 .

- Practise the ways of using the e-tools to build word knowledge of English.

- Own a smartphones or a table and connect to the internet.

- Choose any kinds of pictures they really like.

- After choosing any kinds of pictures, they mention the name of the picture and pair the word whose pole is opposite one another or select a specific word, such as "big."

- Construct the knowledge and solve the problems collaboratively.

- Arrange the word into a continuum or a certain spot/scale.

- Perform the ideas in front of a teacher and other children (other pairs/other groups).

- Enhance their learning, pair/group's discussion, and performance

- Be aware of their thinking process of how and why of the learning needs to be carried out; be responsive to their weakness and strengths and identify steps to improve performance. 
the researcher expected to accomplish; develop analytic questions; review what has been found when collecting data; write experts and observers' comments about ideas generated; note down a diary about what the researchers learnt; explore theories; and try out the ideas on the subjects. Furthermore, the data were then reduced and displayed employing (Miles, M., \& Huberman, 1994) model. In conclusion drawing, described data were further descriptively reported as the final findings of this research. After going through all the research processes, researchers verified and examined the validity of the collected and analysed data, findings, and results through credibility (validity) test by extending research period of time, increasing the persistence of observations, and triangulation. The goals were to build the researchers' belief in the truth of data results, to produce understanding, avoid wrong, bias, and different meshing data while dependability (reliability) test was made use of auditing and reviewed all qualitative research procedures (Cope, 2014).

\section{RESULTS AND DISCUSSION}

\section{Results}

The issues investigated are dealing with understanding and dissimilarity of the meaning of the lexemes (words), meaning relations, and their shades of meaning. The investigated issues after applying the assigned strategy better improve the children's understanding. As illustrated in the following infographic, the results of research using the scientific methods of observation of complete observation, field-note, and unstructured interview designated that the Linguistic intelligences of "word smarts, "lexical meaning smarts," "semantic meaning smart" and "grammatical word order smart" and digital awareness, digital competence, critical thinking skills or higher-order thinking skills were the key effects of using the e-dictionaries-based semantic gradients in understanding and distinguishing the shades of meaning of English. Besides, this research played critical roles in better enhancing the preschool children's 4Cs (Communication, Collaboration, Critical Thinking, and Creativity) and in understanding of spoken and written language along with the abilities to gradually talk and write themselves in English.

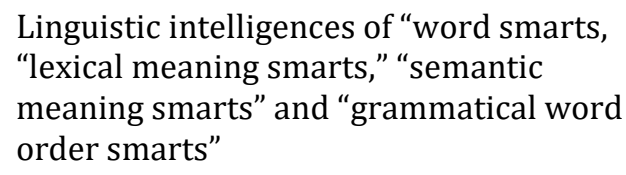

Digital awareness, digital competence, critical thinking skills or higher-order thinking skills

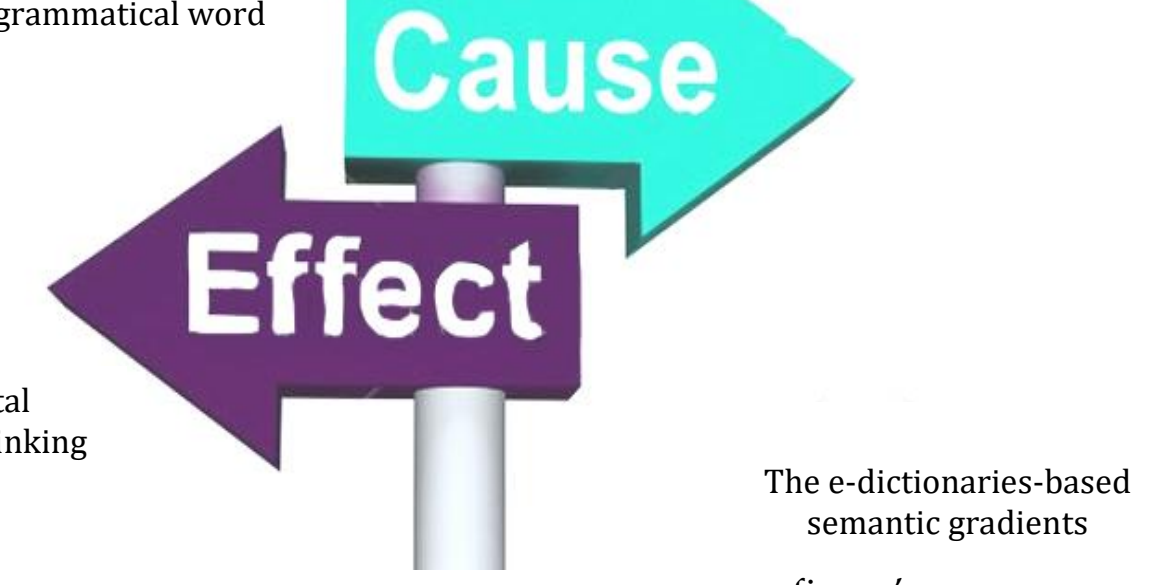

Figure 3. The cause and effects' infographic of

figure's source: career anaa

\section{Discussion}

It turns out that the key points of the significances of this research and its own findings are, firstly, practically enhancing the preschool children linguistic intelligence of "word smarts." The first linguistic intelligence is related to "the word classes of English." During the 
learning and observation processes, the children, who previously were unaware of and understand the English word classes, have started to be capable of recognising and distinguishing the uses and usage of the four major word classes of English. They have been capable of terming that Noun whose key function is to name the objects such as living creatures, objects, places, actions, qualities, states of existence, or ideas; Verb whose major sense is to explain the actions and occurrence; Adjective whose principle is to explicate nouns or noun phrases; Adverb whose critical point of use is to modify or describe a verb, adjective, clause, sentence, or other adverbs. Besides, they can explain that the adverb typically functions to express the manner, place, time, frequency, degree, level of certainty, etc and answer questions such as how, in what way, when, where, and to what extent In the context of teaching and or learning English, the ELT experts and linguists disclose that these four major word classes of English including the other 4 parts of speech such as pronouns, prepositions, conjunctions, and interjections are the bedrocks for the children (language learners) to comprehend how the words function in meaning and correct grammatically within the sentences and the e-tools-assisted semantic gradients is one of the strategies to successfully teach or learn these word classes of English as it assists the children to better distinguish the classes of the words along with the meaning accompanying them (Borer, 2005; Ernst, 2002; Morenberg, 2010; Warren, 1984). Shortly, the preschool children have been able to discern and use the word classes of English smartly and correct grammatically.

The lexical meaning, word meaning, or linguistically known as "lexical definition" is the second linguistic intelligence of "meaning smarts" acquired by the children from the learning process of the e-dictionaries-based semantic gradients. The preschool children's indepth understanding of the lexical meaning of English is, indeed, inseparable from the four major word classes of English whose aspects of meaning or definition along with examples of usage in sentences come from a number of e-dictionaries. During the observation, the children felt contented and in high spirits to use such e-dictionaries. They have the freedom, flexibility and speed in searching for online short stories for kids and looking for the meanings of words. It is due to the e-dictionaries are able to rapidly and easily aid them look for the meanings of the words; quickly show words with more than one meaning, similar and opposite meanings; promptly rectify their understanding of the words defined; hastily understand and able to clearly distinguish parts of speech (word classes); swiftly improve and verify words' spellings, correct pronunciations in which the words are spoken; and significantly enhance and increase the number of words owned in a day. More importantly, the authentic examples of sentences that have been well designed and constructed in such a way in the e-dictionaries allow the children to imitate the instances as well as make it easier for them to develop their new ideas. Similarly, this is in conjunction with a number of empirical studies disclosing that such edictionaries and the 21 digital tools are believed to be able to build the children's SLA; directly listen to and imitate the native speaker's pronunciations; read aloud the words in a wide range of the authentic instances, look at and visualise the photos and figures related to the words which are critical for the children; strengthen the learning of words through interactive games; play with and use the language; find out poetic words and work (learn) together with peers or group of 2 or 4 to create virtual word walls (Tyson, 2016). Besides, the 21 digital tools and other online resources encourage the children to be "word choosy" and assist them to be more contextual, purposeful, and specific in their speaking or writing (Johansen, 2014).

Thirdly, this research helps develop the children's linguistic intelligence of "semantic meaning smarts" in distinguishing the shades of meaning of English words that they previously assumed that the word "brave" is exactly the same meaning and usage as the words "courageous, heroic, daring, gritty, fearless, bold, resolute, etc." Such assumption and knowledge show that they are still incapable of distinguishing the shades of meaning of English words and continuously exploiting the same word for different purposes and contexts. When, for example, they describe a person who is doing an extreme and heroic action, they choose the word "brave" without referring to other words. The use of one word for all contexts 
and purposes shows that they need the e-dictionaries or other digital tools to speed up their access to look for the other shades of meaning of a word and basic knowledge of semantic gradients in making connections between the known word "brave" and the new word "heroic" to aid them to distinguish the shades of meaning of "brave." Even though they are synonym, they now understand that the word "to like" is not the same as "to love, to be fond of, to admire, to be keen on, to delight in, etc." Theoretically, the study of words and meanings along with shades of meaning is closely related to the semantics examining, some of them are, about the meaning of signs and relations between different linguistic units of synonym, antonym, hypernymy, hyponymy, metonymy, etc. These meanings are lexically reflected by their context or constituted by its contextual relations (Cruse, 1986). In addition to it, this research has been able, as the researchers predicted and believe right before doing this study, to enhance the children's pragmatic competence. A competence of understanding the meaning of a word bases on its context as well as the use of words (language) effectively, purposively, and contextually (Löbner, 2002; Slabakova, 2010). Although this has not yet fully appreciated by the children, the results of the observation strongly disclose that they have achieved specific purposes and understood the contexts of using the words. This has been in conjunction with the theory of pragmatic competence divulging that one of the criteria or characteristics of someone who has already had pragmatic competence is a person who has been able to achieve a specific purpose and to understand a language in context (Thomas, 1983). Unfortunately, this competence is not intensively and extensively explored due to time constraints and the focus of research that has already been formulated from the beginning.

The grammatical meaning or structural meaning is the fourth linguistic intelligence of "grammatically word order smarts" which enables the children to put and arrange the words into the correct orders to make sentences. After they knew and understood the basic essences of the word classes of English along with the lexical/word meaning or lexical definition accompanying them, they then followed the basic structures of English sentences consisting of subject, predicate, direct object, indirect object, and complement with sentence patterns and examples made by the children are subject+verb (We pray, She runs fast); subject+verb+object (Rudi rides his bicycle); subject+to be+adjective (He is rich) subject+verb+adjective (the man looks smart); subject+verb+adverb (the oranges are everywhere); subject+verb+noun (Chinny and Santhy are children); and subject+verb+indirect object ${ }^{1}+$ direct object ${ }^{2}$ (she buys her parents ${ }^{1}$ two pairs of shoes ${ }^{2}$ ). The abilities to put the words together to produce a grammatically correct sentence is inseparable from the ability of the children to understand and distinguish the functions of nouns, verbs, adjectives and adverbs along with their functions and meanings. The children really understand that the noun indicating the person, place or thing can be positioned or function as a subject and an (indirect and direct) object within a sentence. They also better understand that a verb functions to show the action of the subject while an object is a word or group of words that are affected by the verb. A correct and good understanding of word order by following the sentence structures and patterns of English; their experiences of reading the online short stories; as well as their efforts to learn the examples of sentences encountered in the online short stories assist the children to successfully write (produce) the correct sentence as some of the examples above. They no longer write jumbled sentences. ELT experts and linguists' theoretical ideas have been in line with this research where their empirical studies and language theories signified that the word classes of English, lexical meaning/definition, and word orders are critical parts of grammatically and syntactically making sentences (Nordquist, 2020a, 2020b; O'Dwyer, 2006).

Fifthly, this e-dictionary-based semantic gradients practically makes the preschool children realise that smartphones, tablets, and other e-tools are essentially not only exploited for the purposes of meeting daily bases such as calling or texting parents, relatives, and friends; playing games, listening to music, shopping, watching movies or meeting other trifling needs but also are capable of bridging them to gradually enhance their general knowledge, vocabulary knowledge including language skills of receptive and productive skills 
contextually, specifically, and extensively. The children's digital awareness leads them to intelligently have started to be capable of utilising their smartphones and tablets and of running out their internet quota or data for supporting and improving the English learning process of theirs and become a means of learning to enrich their up-to-date information, insights, knowledge, and skills of English. Theoretically, the digital awareness (awareness of using the e-tools positively) encourages the learners to learn and acquire numerous contexts of information, facts, and knowledge through collective (social and shared) and content interactions using personal digital devices of theirs and these, of course, provide comfort for them both in terms of accessing information, improving knowledge and skills of English and providing a convenient time to learn (Crescente \& Lee, 2011; Crompton, 2013).

Besides, (Trentin \& Repetto, 2013) explicate that the uses of e-tools such as computers, MP3 players, notebooks, mobile phones and tablet in learning processes contribute to improving the children's informal learning, self-directed learning or learning from their experience. It develops the "heuristic method" of learning involving discovery and problemsolving, using reasoning and past experience. It establishes socialization, enculturation, play, meaningful participation via knowledge creation in contrast to teacher-centre placing emphasis on "knowledge acquisition." The children are encouraged to build their own personal will to learn, to be creative in creating new ideas, to discuss and share with one another online, etc.

In addition to changing the children' lay minds about using smartphones, tablets, and the other e-tools, the research finding leads them to gradually shift the paradigm of theirs regarding the process and interaction of learning English and the learning resources of English exploited. What the preschool children recognise and realise so far are the processes and interactions of learning English only occurred and took place at school. They think of that school is the only place to learn English or to acquire the language. Such a presupposition has long been stuck to their mind because they assume that there has been an English teacher who could facilitate and guide them to learn to acquire the language; teach (how to pronounce a word and what does it refer to) the sound and the meaning of each word; explain the rules of language, for instances, to be: am, is, are; the articles a, an, the, etc. Likewise, a language teacher of English, English dictionary, and books purchased in bookstores or directly ordered through book publishers are considered as the major learning resources of English.

The preschool children's assumptions are, of course, largely correct and acceptable because these are the facts they encounter every time they learn English. Even though it does not seem to notice anything wrong with the process and interaction of learning English along with the learning resources exploited so far, without the help or touch of digital technology and tools; these, of course, prevent them from enhancing their knowledge and skills of English. These are because they just have little time to learn and interact with their teacher; the scope, environment, area, opportunity and facilities to learn and to acquire the language are insufficient; and the learning resources and information (facts and knowledge) obtained from their language teacher expected to master are too little. The limitations and dependence on non-digital learning systems, processes and resources hinder, encumber, and thwart the children's pace, move (action), and speed to easily improve and develop their vocabulary knowledge and language skills of English; to rapidly access the meaningful information; to learn something new; to critically think; to share ideas; to imitate, to adopt, to adapt to, and to accept one's ideas; to aid them to remember, understand, and apply the information in their new forms and situation; and more importantly to search for the ways of learning to analyse, evaluate, and use the information (facts and knowledge) accessed to create something new ideas.

Sixthly, this research finding significantly contributes to improving the preschool children's digital competence in learning English. The fact is the children have started to have high self-confidence and are increasingly critical in employing digital ICT tools. Besides, they are smart enough to filter and access various information required for the benefit of improving 
and developing their English. Similarly, the finding of this study is in line with the results of previous studies which explain that the digital competence is a competence that raises a sense of confidence and a critical sense of the use of digital technology devices in regain, measure, store, producing, presenting and exchanging information (facts and knowledge), and communicating and engaging in collaborative networks via the Internet. The competence digital competence- affects the children's high exposure to English -incomparable prospects and chances to exercise EFL and actively involves with the authentic real-world contexts of language use (Ilomäki, L., Kantosalo, A., \& Lakkala, 2011; Prensky, 2001). Besides, they do a lot of things with that language rather than just listen to it learn about it. Competence can enhance the children's English language learning motivation to recover and advance their communication competence in English. This is a very constructive and beneficial way of allowing them to appreciate English and its culture, as personalisation (autonomous) learning approach and velocity could be provided for. The competence can improve children's learning autonomy and management (organisation), provide a more children-centred language learning with the children at the axis or heart of the instructional process and more enthusiastically involved in their learning when compared to the non-digital instruction approaches (Jewell, 2006).

Other than that, the Critical Thinking Skills (CTSs) or Higher-Order Thinking Skills (HOTs) are the last critical effect of the e-dictionary-based semantic gradients. The CTSs are clearly seen when the children make connections between known words and new words (vocabulary) and put/arrange the known words and new words into sentences. The processes are, after reading the online short stories they really like, they, firstly, determined and decided the theme or topic (what type of word, for example, nouns, adjectives, verbs, etc) of the semantic gradient. The theme that has been determined is for example, "beautiful." They afterwards look for the new words that connect to the fixed theme, "beautiful" using the edictionaries and or other 21 digital tools. The uses of these e-dictionaries and digital tools are to help and ensure them that the theme is really closely related to the new words: "attractive, pretty, lovely, stunning, charming, tempting, gorgeous, etc" even though these words, are not always considered or often used as a synonym for "beautiful." Besides, the e-dictionaries and tools are to essentially mean to make the children's learning process faster and the assigned tasks are easier to accomplish.

In making connections between known words and new words and discerning their shades of meanings, they, the very first steps, list and arrange the related words into semantic gradients; identify and describe the shades of meaning of the words, and recall the words and their meanings into their long-term memory. Secondly, they then collaboratively discuss, explain and make senses of the concepts of words, meaning, meaning relations, and shades of meaning. Thirdly, they use the information and knowledge to develop their ideas. Fourthly, they semantically distinguish the lexical meanings of the known words and new words and explore their relationships (similarity and differences). Fifthly, from the results of the teacher's explanation and the pairs or groups' discussions, they then re-justify (to show or prove that it is reasonable, necessary, or logical) the results of their analysis, and they, finally, create (write or make) own sentences. These six steps are the processes of building the children's very basic level of knowledge of CTSs/HOTs to the highest ones. Identifying problems/proposing questions to find solutions, collecting more sources, analysing and assessing the sources, identifying assumption (best guest), establishing important information to solving the problems, drawing a conclusion and present or articulate their words to their teacher and classmates are other key stages of developing the children's CTSs/HOTs. The success of establishing and developing the children's CTSs/HOTs is because, in the learning process, they are capable of sharing ideas, solutions, and questions (communication), working and learning collaboratively (collaboration), thinking critically (critical thinking), and making efforts new methods and techniques to the learning and tasks are done and well accomplished (creativity). 
The whole sequences of learning processes and activities using the e-dictionaries-based semantic gradients to show that the number of English words of each student possessed and mastered is 100 words per week or approximately 33 words per meeting where there were three times meetings in a week. The digits strongly designate that this research aids the children to make connections between known words and new words and discern the shades of meaning of English words. More to the point, it better enhances preschool children English word's (vocabularies) ownership and the mastery and this makes them have skills and abilities to understand and communicate the written and spoken language of English. The edictionaries-based semantic gradients effectively help the children to become practical vocabulary builders, connection-makers between known words and new words, the distinguishing persons for the shades of word meanings, and smart word choosy.

\section{CONCLUSION}

To sum up, the e-dictionaries-based semantic gradient is one of the expected language teaching strategies of English enabling preschool children to make connections between known lexis and new vocabulary as well as helping them to significantly develop and multiply the number of their new vocabulary. This study, therefore, encourages English teachers to apply it to improve the children's understanding and mastery of the English words along with their meanings and shades of meaning, long-term memory to lexically remember and comprehend the meanings or definitions of the words. Besides, it is to aid the children develop their productive skills of speaking and writing.

\section{Acknowledgement}

I would like to express my special thanks to the Director of Padang State Polytechnic, Dr. Surfa Yondri, ST., SST., M.Kom facilitating the implementation of this research. I would like to thank the children in the Bumiminang complex and its surroundings for being willing to become our research participants. Finally, I would like to thank my fellow Doctors of Education Sciences who have been willing to provide constructive suggestions and inputs to improve the results of this research.

\section{REFERENCES}

Andriyani, E. (2013). Semantics (synonym, antonym, homonym, hyponym, polyseme, idioms). https:/ / www.slideshare.net/Andriyanieka12/13-semantics-synonym-antonymhomonym-hyponym-polyseme-idioms-18509523.

Ateah, C. A., Scott, S. D., \& Kyle, T. (2008). Canadian Essentials of Pediatric Nursing. China: Wolters Kluwer Lippincott Williams \& Wilkins., 82-84.

Barcroft, J., Sunderman, G., \& Lexis, N. S. S. E.-. (2011). Lexis. In The Routledge Handbook of Applied Linguistics. Routledge. https:// doi.org/10.4324/9780203835654.ch40

Bogdan, R. C., \& Biklen, S. K. (2006). Qualitative research in education: An introduction to theory and methods. Allyn \& Bacon.

Bolden, Bill. (2020). Shades of Meaning: A lesson in Semantic Gradients. OSSPEAC. https://osspeac.org/wp-content/uploads/2020/05/Semantic-Gradients-BillBolden.pdf.

Borer, H. (2005). In Name Only. Structuring Sense. Oxford: Oxford University Press. https:// doi.org/10.1093/acprof:oso/9780199263905.001.0001

Brandone, C, A., Salkind, S. J., Golinkoff, R. M., Hirsh-Pasek, K., Bear, G. G., \& Minke, K. M. (2006). Language Development. Children's needs III : development, prevention, and intervention. Bethesda, Md: National Association of School Psychologists.

Brown, H. D. (2007). Teaching by principles : an interactive approach to language pedagogy. Pearson Education. 
Brown, R. (1974). A first language: the early stages. Journal of Child Language, 1(2), 289-307. https:// doi.org/10.1017/S030500090000074X

Bull, S., \& Ma, Y. (2001). Raising learner awareness of language learning strategies in situations of limited recourses. Interactive Learning Environment. https://doi.org/10.1076/ilee.9.2.171.7439

Canfield, M. (2011). Field Notes on Science \& Nature. Harvard University Press. https:// doi.org/10.4159/harvard.9780674060845

Chilisa, B. (2012). Indigenous research methodologies. SAGE.

Christensen, Johnson, B., \& Larry. (2012). Educational research : quantitative, qualitative, and mixed approaches (4th ed.). Educational Research.

Conti-Ramsden, G., \& Durkin, K. (2012). Language development and assessment in the preschool period. Neuropsychology Review, 22(4), 384-401. https:// doi.org/10.1007/s11065-012-9208-z

Cope, D. G. (2014). Methods and Meanings: Credibility and Trustworthiness of Qualitative $\begin{array}{lllll}\text { Research. Oncology Nursing } & \text { Forum, 41(1), 89-91. }\end{array}$ https:// doi.org/10.1188/14.ONF.89-91

Crais, E. R., Watson, L. R., \& Baranek, G. T. (2009). Use of gesture development in profiling children's prelinguistic communication skills. American Journal of Speech-Language Pathology, 18(1), 95-108. https:// doi.org/10.1044/1058-0360(2008/07-0041)

Crescente, M. L., \& Lee, D. (2011). Critical issues of m-learning: design models, adoption processes, and future trends. Journal of the Chinese Institute of Industrial Engineers, 28(2), 111-123. https:/ / doi.org/10.1080/10170669.2010.548856

Crompton, H. (2013). A historical overview of mobile learning: Toward learner-centered education". In Handbook of mobile learning (pp. 3-14). Florence, KY: Routledge.

Cruse, D. A. (1986). Lexical Semantics (Cambridge Textbooks in Linguistics). Cambridge University Press.

Ernst, T. (2002). The syntax of adjunct. Cambridge University Press.

Fernández-Martínez, F., Zablotskaya, K., \& Minker, W. (2012). Text categorization methods for automatic estimation of verbal intelligence. Expert Systems with Applications, 39(10), 9807-9820. https://doi.org/10.1016/j.eswa.2012.02.173

Fontenot, Karen Anding. (2018). "Nonverbal communication and social cognition". Salem Press Encyclopedia of Health. 4: 4.

Frank, M. (1972). Modern English: Exercises for Non-Native Speakers Part II Sentences and Complex Structures. New Jersey: Prentice-Hall.

Friederici, A. D. (2011). The brain basis of language processing: From structure to function. Physiological Reviews, 91(4), 1357-1392. https://doi.org/10.1152/physrev.00006.2011

Given, L. (2008). Convenience Sample. In The SAGE Encyclopedia of Qualitative Research Methods. SAGE Publications. https:// doi.org/10.4135/9781412963909.n68

Greenwood, S. C., \& Flanigan, K. (2007). Overlapping Vocabulary and Comprehension: Context Clues Complement Semantic Gradients. The Reading Teacher, 61(3), 249-254. https:// doi.org/10.1598/RT.61.3.5

Hakim, A. (2018). Characteristics of a language. English Finders. https://englishfinders.com/characteristics-of-language/

Halliday, M. A. K., \& Yallop, C. (2007). Lexicology: a short introduction. Continuum. http:// public.ebookcentral.proquest.com/choice/publicfullrecord.aspx? $p=742475$

Haslett, B. B., \& Samter, W. (1997). Developing verbal communication In Children communicating. Behavioral Sciences, Humanities. https://doi.org/10.4324/9781003063933

Henry, G. T. (1990). Practical sampling. SAGE Publications. https://doi.org/10.4135/9781412985451

Ilomäki, L., Kantosalo, A., \& Lakkala, M. (2011). What is digital competence? In Linked portal, European Schoolnet. http://linked.eun.org/web/guest/in-depth3. 
Ide, N. \& Véronis., J. (1998). "Word sense disambiguation: the state of the art". Computational Linguistics. 24: 1-40.

İter, B. G. (2015). How does Technology Affect Language Learning Process at an Early Age? Procedia - Social and Behavioral Sciences, 199, 311-316. https://doi.org/10.1016/j.sbspro.2015.07.552

Jewell, M. (2006). Real-world contexts, skills and service learning for secondary school language learners. In E. Hanson-Smith, and S. Rilling (eds.). Learning Languages through Technology.

Johansen, D. (2014). Be "Word Choosy" with Word Gradients. LITLEARNACT Two Literacy Teachers Learning and Sharing in the Blended Learning Classroom. https:/ / litlearnact.wordpress.com/2014/04/14/be-word-choosy-with-wordgradients/

Katzner, K., \& Miller, K. (2002). The Languages of the World. In K. Katzner (Ed.), Language \& Literature. Routledge. https:// doi.org/10.4324/9780203430163

Kennison, S. M. (2014). Introduction to Language Development. https://doi.org/10.4135/9781506374499

Kovalenko, G. (2011). Lexicology of the English Language.

Krauss, S. (2005). "Research Paradigms and Meaning Making: A Primer." The Qualitative Report, 10(4), 758-770.

Labaree, R. V. (2020). "Research Guides: Organizing Your Social Sciences Research Paper: Writing Field Notes." https:// libguides.usc.edu/writingguide/fieldnotes.

Larson, M. L. (1984). Meaning-based translation: A guide to cross-language equivalence. University press of America.

Levin, B., Amp, \& Pinker, S. (1991). Lexical and Conceptual Semantics. Journal of Linguistics, 30(2), 574-575. https://doi.org/10.1017/S0022226700016856

Lewis. M. (1993). The Lexical Approach. Hove: Language Teaching Publications.

Lewis. M. (2002). Teaching Collocations. LTP, Hove.

Löbner, S. (2002). Understanding Semantics. Linguistics, 43, 443-448. https://doi.org/10.1515/ling.2005.43.2.443

Luinge, M. R., Post, W. J., Wit, H. P., \& Goorhuis-Brouwer, S. M. (2006). The ordering of milestones in language development for children from 1 to 6 years of age. Journal of Speech, Language, and Hearing Research: JSLHR, 49(5), 923-940. https://doi.org/10.1044/1092-4388(2006/067)

Mardhotillah, Huda \& Rakimahwati. (2021). Pengembangan Game Interaktif Berbasis Android untuk Meningkatkan Kemampuan Membaca Anak Usia Dini. Jurnal Obsesi: $\begin{array}{lllll}\text { Jurnal Pendidikan Anak Usia } & \text { Dini, }\end{array}$ https://doi.org/10.31004/obsesi.v6i2.1361

Miles, M., \& Huberman, A. (1994). Qualitative data analysis (2nd Ed.). In An expanded sourcebook. SAGE Publications.

Morenberg, M. (2010). Doing Grammar (Third ed.). Oxford University Press.

Nation, I. S. P. (2001). Learning Vocabulary in Another Language. Cambridge University Press. https://doi.org/10.1017/CBO9781139524759

Ningsih, Y., S, \& Mahyuddin, N. (2021). Desain E-Module Tematik Berbasis Kesantunan Berbahasa Anak Usia Dini di Taman Kanak-Kanak, Jurnal Obsesi: Jurnal Pendidikan Anak Usia Dini, 6(1), 137-149. https://doi.org/10.31004/obsesi.v6i1.1217

Nordquist, R. (2020a). Sentence Parts and Sentence Structures. https://www.thoughtco.com/sentence-parts-and-sentence-structures-1689671.

Nordquist, R. (2020b). What Is Grammatical Meaning. https://www.thoughtco.com/ what-isgrammatical-meaning-1690907

O'Dwyer, B. (2006). Modern English Structures: Form, Function, and Position. 2nd Edition. Broadview Press: Peterborough, Ontario Canada.

Pettigrew, J. (1995). Teaching Vocabulary: Two Dozen Tips \& Techniques. 1995, 1-8. 
Prensky, M. (2001). Digital Natives, Digital Immigrants (pp. 1-6). Lincoln, NCB University Press. https://doi.org/10.1108/10748120110424843

Renkema, J. (1993). Discourse Analysis: An Introductory Textbook. Philadelphia: John Benjamin. https://doi.org/10.1075/z.69

Schmitt, N. (2010). Researching Vocabulary. Palgrave Macmillan UK. https:// doi.org/10.1057/9780230293977

Slabakova, R. (2010). Semantic Theory and Second Language Acquisition. Annual Review of Applied Linguistics, 30, 231-247. https:// doi.org/10.1017/S0267190510000139

Smith, M. (2005). "AAC: Augmentative \& Alternative Communication". The Dual Challenges of Aided Communication and Adolescence. 21, 67-79. https://doi.org/10.1080/10428190400006625

Steven A. Stahl, W. E. N. (2006). Teaching Word Meanings. Routledge. https://doi.org/10.4324/9781410615381

Strom, R., Bernard, H., \& Strom, S. (1987). Fostering effective communication. In Human Development and Learning. New York, NY: Human Sciences Press., 270-278.

SWG, S. W. G. (2020). Teaching Methods for Spelling. https://www.sightwordsgame.com/spelling/teaching-methods-for-spelling/

Teddlie, C., \& Yu, F. (2007). WITHDRAWN - Mixed Methods Sampling. Journal of Mixed Methods Research, 1(1), NP1-NP1. https:// doi.org/10.1177/2345678906292430

Thomas, J. (1983). Crosscultural pragmatic failure. Applied Linguistics, 4(2), 91-112. https://doi.org/10.1093/applin/4.2.91

Tomlinson, B. (2012). Materials development for language learning and teaching. Language Teaching, 45(2), 143-179. https:// doi.org/10.1017/S0261444811000528

Trask, R. L. (2007). Language and Linguistics: The Key Concepts (P. Stockwell (ed.)). Routledge. https://doi.org/10.4324/9780203961131

Trentin, G., \& Repetto, M. (2013). Using Network and Mobile Technology to Bridge Formal and Informal Learning. Woodhead/Chandos Publishing Limited, Cambridge, UK. https:// doi.org/10.1533/9781780633626

Trilling, B., \& Fadel, C. (2009). 21st Century Skills: Learning for Life in Our Times. San Francisco, CA: Jossey-Bass., 256.

Tyson, K. (2016). 21 Digital Tools To Build Vocabulary. TeachThought Staff. https://www.teachthought.com/literacy/21-digital-tools-build-vocabulary

Ur, P. (2012). A course in English language teaching. In Cambridge. New York University Press. https:// doi.org/10.1017/9781009024518

Warren, B. (1984). Classifying adjectives. Gothenburg Studies in English (No. 56). Göteborg: Acta Universitatis Gothoburgensis.

Wilkins, D. A. (1972). Linguistics in Language Teaching (E. Arnold (ed.)).

Wright, Julius Sim, C. (2002). concepts, designs and methods (Reprinted. ed.). Research in Health Care.

Yusuf, M. (2014). Metode Penelitian: Kuantitatif, Kualitatif dan Penelitian Gabungan (Research Methods: Quantitative, Qualitative and Mixed Methods). Rawamangun-Jakarta: Prenadamedia Group. 